\title{
Pengaruh Komitmen Organisasional, Perencanaan Karir, dan Motivasi terhadap Kinerja Karyawan
}

\author{
Miswanto $^{\bowtie}$, Eggi Sandy Tesa, Bambang Setia Wibowo \\ Sekolah Tinggi Ilmu Ekonomi YKPN, Yogyakarta \\ e-mail: miswanto.ykpn@gmail.com
}

\section{Abstract}

This study aims to examine the effect of organizational commitment, career planning, and motivation on employee performance. Data collection was carried out through distributing questionnaires with 101 employee respondents who work in business organizations. The sampling technique used was purposive sampling and the data analysis method used was multiple linear regression. The results of this study indicate the following. Organizational commitment has no significant effect on employee performance. Career planning has a significant positive effect on employee performance. Motivation has a significant positive effect on employee performance. Simultaneously organizational commitment, career planning, and motivation affect employee performance.

Keywords: Career planning, employee performance, organizational commitment, motivation

\begin{abstract}
Abstrak
Maksud penelitian ini adalah untuk menguji apakah komitmen organisasional, perencanaan karir, dan motivasi berpengaruh pada kinerja karyawan. Pengumpulan data dilakukan melalui penyebaran kuesioner dengan 101 responden karyawan yang berkerja pada organisasi bisnis. Teknik sampling menggunakan purposive sampling dan metode analisis datanya adalah regresi linear berganda. Temuan penelitian ini mengindikasikan seperti berikut. Komitmen organisasional tidak berpengaruh signifikan pada kinerja karyawan. Perencanaan karir signifikan berpengaruh positif pada kinerja karyawan. Motivasi signifikan berpengaruh positif terhadap kinerja karyawan. Secara simultan komitmen organisasional, perencanaan karir, dan motivasi memiliki pengaruh pada kinerja karyawan.
\end{abstract}

Kata kunci: Kinerja karyawan, komitmen organisasional, motivasi, perencanaan karir 


\section{PENDAHULUAN}

Kinerja atau prestasi merupakan pencapaian dari proses kerja yang terjalin, diperoleh dari individu itu sendiri (internal factor) ataupun upaya strategis dari organisasi (Wijaya \& Prabandari, 2019). Bagi perusahaan memperhatikan individu adalah hal penting karena individu tersebut adalah sumber daya manusia organisasi yang harus dijaga, dibimbing, dan diinformasikan terutama mengenai standar kinerja indvidu yang diberlakukan dalam organisasi.

Allen \& Meyer (1993) mengatakan jika karyawan yang mempunyai komitmen terhadap organisasi cenderung bekerja dengan dedikasi. Komitmen membuat karyawan memiliki keinginan untuk bekerja dan bertanggungjawab dalam mendorong keberhasilan perusahaan tempat mereka bekerja. Dimilikinya komitmen dalam diri setiap karyawan merupakan hal yang menguntungkan bagi perusahaan, karena karyawan cenderung menunjukkan komitmen mereka melalui kontribusi terhadap perusahaan yang ditunjukkan oleh hasil kinerja.

Perencanaan karir merupakan proses seorang individu merumuskan tujuan atau sasaran karir dan mengembangkan sebuah rencana untuk mencapai tujuan tersebut (Byars \& Rue, 2008). Perencanaan karir dan pengembangan karir harus menguatkan satu sama lain, yang disertai oleh tujuan atau sasaran yang realistis. Perusahaan memiliki tanggung jawab untuk pengembangan karir karyawan. Sumber informasi potensial yang dimiliki organisasi dapat digunakan untuk menilai potensi, kemampuan, dan keahlian karyawan(Byars \& Rue, 2008). Hal inipenting untuk mendukung karyawan mengetahui potensi dan penilaian kemampuan kinerja mereka saat ini, agar dapat meningkatkan dan mempersiapkan diri menjadi lebih baik demi bertahan dalam persaingan.
Analisis yang dilakukan oleh Robbins \& Judge (2009) menyatakan bahwa, tingkat motivasi setiap orang bervariasi pada waktu yang berbeda. Beberapa individu dalam organisasi perlu diarahkan untuk menjadi lebih mandiri dan memiliki kesadaran terhadap pentingnya bertindak mengembangkan potensi dan kemampuan. Mengkomunikasikan kondisi persaingan saat ini dan visi organisasi, agar para individu menyadari pentingnya mempertahankan diri mengimbangi perubahan lingkungan yang menumbuhkan persaingan kompetitif, harus dilakukan oleh perusahaan.

Pada penelitian-penelitian sebelumnya pengujian dilakukan secara terpisah variabel-variabel independen terhadap kinerja karyawan. Dalam studi ini dilakukan pengujian variabel komitmen organisasional, perencanaan karir, dan motivasi pengaruhnya terhadap kinerja karyawan secara bersamaan. Penelitian-penelitian sebelumnya, tidak ditemukan studi pengaruh variabel komitmen organisasional, perencanaan karir, dan motivasi pada kinerja karyawan secara simultan, ketiga variabel independen ini juga terbentuk dan berasal dari diri individu. Selain itu, penelitian ini untuk menguji ulang penelitiannya Murty \& Hudiwinarsih (2012), yang menemukan bahwa komitmen organisasional tidak mempengaruhi variabel kinerja karyawan. Penelitian Rimper \& Kawet (2014), tentang pengaruh perencanaan karir pada kinerja karyawan, yang hasilnya perencanaan karir tidak mampu mempengaruhi dengan signifikan variabel kinerja karyawan. Maksud penelitian ini adalah untuk menguji: 1) pengaruh komitmen organisasional pada kinerja karyawan, 2) pengaruh perencanaan karir terhadap pada karyawan, dan 3) pengaruh motivasi pada kinerja karyawan.

Komitmen organisasional digambarkan sebagai kondisi seorang individu atau karyawan yang berpihak pada organisasi tempat mereka bekerja dan tujuan untuk 
Pengaruh Komitmen Organisasional, Perencanaan Karir,... (Miswanto, Eggi Sandy Tesa, Bambang S.)

mempertahankan diri sebagai anggota organisasi. Komitmen organisasional menurut Robbins \& Judge (2009) yaitu tingginya keterlibatan pekerjaan berarti karyawan memihak pada suatu pekerjaan tertentu. Menurut Brown \& Leigh (1996), komitmen organisasional menjadi lebih penting karena organisasi harus mencari pembenaran bahwa orang-orang yang memberikan nilai tambah pada intinya ingin berkomitmen dalam organisasi dan terus menuangkan usaha mereka ke dalam pekerjaan mereka untuk manfaat organisasi

Zurnali \& Nadeak (2010) menyampaikan bahwa komitmen organisasional adalah perasaan yang erat dan kuat dari seorang individu pada nilai dan tujuan organisasi yang berkaitan dengan peran individu pada usaha mencapai nilai dan tujuan organisasi. Penelitian mengenai komitmen organisasional telah mencoba menganalisis sumber daya manusia perusahaan yang berkaitan dengan pekerjaan di bidang teknologi informasi dan komunikasi pada perusahaan. Definisi komitmen organisasional menurut Zurnali \& Nadeak (2010) seperti berikut. Pertama, komitmen afektif dijelaskan sebagai perasaan pada organisasi yang menunjukkan keinginan untuk menetap dan membangun hubungan sosial juga menghargai hubungan antara nilai dan organisasi. Kedua, komitmen berkelanjutan dijelaskan sebagai perasaan bimbang apabila keluar dari perusahaan karena kebutuhan yang berkenaan dengan penghargaan dari partisipasi dalam organisasi dan pertimbangan biaya jika keluar dari perusahaan. Ketiga, komitmen normatif dijelaskan sebagai perasaan yang membuat individu bertahan dengan perusahaan karena kewajiban atau tanggung jawab pada perusahaan berdasarkan pada nilai, norma, dan keyakinan karyawan.

Perencanaan karir merupakan proses seorang individu merumuskan tujuan atau sasaran karir dan mengembangkan sebuah perencanaan demi mencapai tujuan tersebut
(Byars \& Rue, 2008). Perencanaan karir cenderung meningkatkan perjuangan karir, adaptasi terhadap perubahan kondisi, dan ketahanan dalam menghadapi hambatan karir (London \& Noe, 1997). Mengacu pada referensi tersebut, dapat dinyatakan bahwa kegiatan dan kesepakatan diberikan perusahaan untuk membantu karyawan mencapai tujuan karir mereka. Hal terpenting yaitu karyawan diharapkan untuk meningkatkan kompetensi dan kemampuan.

Perencanaan karir jika dilihat dari manfaatnya akan berdampak pada dua pihak yaitu perusahaan dan karyawan yang memiliki perencanaan terhadap karir. Tujuan perencanaan karir karyawan mampu mendorong pertumbuhan perusahaan. Hal ini dikarenakan karyawan yang terdorong oleh tujuan karir mereka memiliki semangat dan motivasi melakukan pekerjaan dengan baik agar memperoleh penilaian yang baik pula dari organisasi.

Pada tahun 1950an menjadi era berkembangnya konsep motivasi, empat teori spesifik telah diformulasikan selama periode ini (Robbins \& Judge, 2009). Teori-teori ini mewakili dasar di mana teori kontemporer telah tumbuh, dan praktik manajer masih secara teratur menggunakan teori ini, dan terminologi mereka dalam menjelaskan motivasi karyawan (Robbins \& Judge, 2009). Menurut McClelland seseorang yang dianggap memiliki motivasi prestasi yang tinggi jika seseorang berkeinginan untuk mempunyai prestasi lebih baik dari pada orang lain pada berbagai situasi. Kemudian, teori ini menekankan pada tiga kebutuhan. Pertama, kebutuhan berprestasi adalah keinginan untuk menggapai hal yang berkaitan dengan standar, untuk berusaha mencapai hasil. Kedua, kebutuhan kekuasaan adalah dorongan untuk menjadikan orang lain berperilaku dengan cara tidak akan berperilaku sebaliknya. Ketiga, kebutuhan afiliasi adalah dorongan untuk memiliki hubungan antar personal yang bersahabat. 
Dari ketiga kebutuhan di atas, McClelland berfokus pada kebutuhan berprestasi. Orang yang berprestasi tinggi memiliki kinerja terbaik saat mereka melihat kemungkinan untuk sukses paling sedikit adalah 50\%. Yaitu, ketika mereka mengestimasi bahwa mereka memiliki kemungkinan berhasil 50-50 untuk sukses (Robbins \& Judge, 2009). McClelland berpendapat bahwa tiga kebutuhan bawah sadar mungkin lebih tinggi tetapi tidak diketahui, karena mengukur kebutuhan ini tidak mudah.

Kirk \& O'Connell (2012) menganggap kinerja sebagai catatan karyawan yang mencapai hasil kerja dalam periode tertentu. Penilaian kinerja dilakukan oleh perusahaan terhadap karyawan dengan melihat proses dan hasil kerja karyawan melalui sistem formal yang terstruktur dan adil. Penilaian kinerja tidak hanya membuat karyawan mengetahui kinerja mereka, tapi juga mempengaruhi tingkat usaha di masa depan dan pengarahan tugas (Byars \& Rue, 2008).

Penilaian kinerja karyawan menurut Byars \& Rue (2008) adalah sebuah proses evaluasi dan komunikasi pada karyawan perihal bagaimana mereka melakukan pekerjaannya dan membangun sebuah rencana yang terus diperbaiki. Penilaian yang diberikan perusahaan dapat memicu karyawan untuk mempertahankan kinerja mereka atau berusaha lebih meningkatkan kinerjanya. Terdapat beberapa indikator yang dijadikan tolok ukur kinerja karyawan. Pertama, loyalitas, tingkat loyalitas karyawan yang tinggi pada perusahaan yang menaungi mereka memberikan peluang posisi yang baik, loyalitas dapat dilihat pada presensi dan kinerja karyawan. Kedua, semangat kerja, suasana lingkungan kerja yang kondusif penting bagi karyawan karena kondisi lingkungan yang nyaman bagi karyawan akan menjaga semangat kerja. Ketiga, kepemimpinan, sikap pemimpin yang ditujukan pada karyawan dengan mengikutsertakan mereka dalam pemecahan masalah atau proses lainnya, membuat karyawan merasa dibutuhkan. Keempat, kerja sama, budaya kerja sama yang tumbuh dalam organisasi memberikan kesan kekeluargaan. Keenam, tanggung jawab, sikap bertanggungjawab membuat karyawan melakukan tugas seperti yang menjadi tanggung jawab mereka.

\section{Pengembangan Hipotesis}

Murty \& Hudiwinarsih mendapat temuan bahwa variabel komitmen organisasional tidak berpengaruh terhadap kinerja karyawan. Ada beberapa temuan yang mengindikasikan bahwa komitmen organisasional berpengaruh positif terhadap kinerja karyawan. Fitriastuti (2013) menemukan bahwa salah satu variabel independen yaitu variabel komitmen organisasional berpengaruh positif pada kinerja karyawan. Kemudian, temuan Ticoalu (2013) mengindikasikan bahwa komitmen organisasional signifikan berpengaruh pada kinerja karyawan.

Shaputra \& Hendriani menemukan bahwa komitmen organisasional karyawan PT BRI (Persero) kantor Wilayah Pekanbaru signifikan berpengaruh pada kinerja karyawan. Sedangkan Nydia (2012) menemukan bahwa komitmen organisasional karyawan lapangan SPBU COCO Pertamina Mt. Haryono yang terdiri atas komitmen afektif, normatif, dan terus menerus secara simultan berpengaruh pada kinerja karyawan. Mengacu penelitian-penelitian sebelumnya tersebut diusulkan hipotesis berikut:

Hipotesis1: Komitmen organisasional berpengaruh positif pada kinerja karyawan.

Rimper \& Kawet (2014) menemukan bahwa perencanaan karir karyawan PT PLN (Persero) Area Manado berpengaruh secara simultan pada kinerja karyawan. Massie (2015) meneliti pegawai Museum Negeri di Provinsi Sulawesi Utara. Temuannya, ada 
Pengaruh Komitmen Organisasional, Perencanaan Karir,... (Miswanto, Eggi Sandy Tesa, Bambang S.)

pengaruh secara positif dan signifikan variabel perencanaan karir pada kinerja karyawan Museum Negeri di provinsi tersebut.

Sugiharjo \& Rustinah (2017) menemukan hasil perencanaan karir karyawan di Jambuluwuk Puncak Resort signifikan berpengaruh positif pada kinerja karyawan. Sedangkan penelitian Mulyadi, dkk. (2018) mengenai pengaruh perencanaan karir pada kinerja karyawan, menemukan bahwa perencanaan karir karyawan PT BNI (Persero) Tbk Samarinda signifikan berpengaruh positif terhadap kinerja mereka. Mengacu hasil penelitian sebelumnya diusulkan hipotesis berikut:

Hipotesis 2: Perencanaan karir berpengaruh positif pada kinerja karyawan.

Paputungan (2013) pada penelitian mengenai pengaruh motivasi kinerja karyawan pada PT Bank Sulut untuk Cabang Calaca menemukan bahwa motivasi karyawan mempunyai pengaruh terhadap kinerjanya. Sedangkan penelitian Harlie (2012) menemukan bahwa secara simultan variabel independen, yaitu motivasi dan pengembangan karir benar-benar memiliki pengaruh pada kinerja karyawan. Mengacu hasil penelitian sebelumnya diusulkan hipotesis berikut:

Hipotesis 3: Motivasi berpengaruh positif pada kinerja karyawan.

Berdasarkan ketiga hipotesis tersebut, model penelitian ini digambarkan pada Gambar 1.

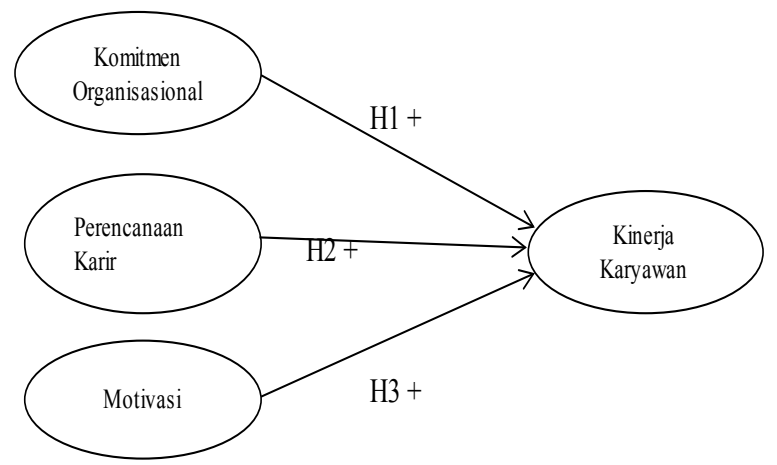

Gambar 1. Model Penelitian

\section{METODE PENELITIAN}

Topik penelitian ini adalah tergolong penelitian dasar yang bersifat teoritis dan diklasifikasikan dalam penelitian deduktif atau penelitian untuk menguji teori atau hipotesis. Pengumpulan sampel didasarkan pada Non-Probability Sampling, yaitu hanya beberapa populasi yang memiliki kemungkinan untuk dijadikan sampel. Penelitian ini menggunakan metode Purposive Sampling, karena sampel dipilih sesuai dengan tolok ukur yang diberlakukan dalam penelitian (Algifari, 2013). Tolok ukur yang dijadikan patokan penelitian ini yaitu karyawan yang bekerja pada organisasi bisnis. Data yang dikumpulkan adalah data primer, yakni data yang diterima langsung dari sumber responden dan subjek yang diteliti (Indriantoro \& Supomo, 2016). Teknik yang diterapkan untuk mendapatkan data primer yaitu menggunakan instrumen kuesioner dengan skala likert kepada responden yang memenuhi kriteria pemilihan sampel.

Komitmen organisasional digambarkan sebagai keadaan seorang individu atau karyawan yang memihak pada organisasi tempat mereka bekerja dan tujuan untuk mempertahankan diri sebagai anggota organisasi. Perencanaan karir (X2) merupakan proses seorang individu merumuskan tujuan atau sasaran karir dan mengembangkan sebuah rencana untuk meraih tujuan tersebut (Byars \& Rue, 2008). Motivasi (X3) merupakan dorongan intrinsik dari dalam dan tidak dapat diberlakukan dari luar, karena motivasi datang dari keinginan seseorang untuk melakukan suatu hal (Baldoni, 2005). Variabel terikat atau dependen (Y) dipengaruhi variabel bebas atau independen (X). Studi yang dilakukan ini, variabel dependennya adalah kinerja karyawan. Mengutip dari Kirk \& O'Connell (2012), kinerja karyawan adalah berupa catatan hasil atau prestasi kerja karyawan dalam kurun waktu tertentu. Pendefinisian variabel, dimensi/indikator, dan item pertanyaan tersaji di Tabel 1 . 
Tabel 1. Variabel, Dimensi/Indikator, Nomor Item dan Jumlah

\begin{tabular}{clllc}
\hline No. & \multicolumn{1}{c}{ Variabel } & \multicolumn{1}{c}{ Dimensi } & \multicolumn{1}{c}{ Nomor item } & Jumlah \\
\hline 1. & Komitmen organisasional (Spik, & Komitmen afektif & $1,2,3,4$, dan 5 & 5 \\
& 2016) dan (Setiawan, 2011) & Komitmen kontinyu & 6,7 , dan 8 & 3 \\
& & Komitmen normatif & 9,10 , dan 11 & 3 \\
2. & Perencanaan karir (Kaya \& & Evaluasi dan penilaian diri individu & 12 dan 13 & 2 \\
& Zerenler, 2014) dan (McAuliffe & Deskripsi kesempatan peluang karir & 14 dan 15 & 2 \\
& dkk., 2006) & Penentuan target dan perencanaan karir & 16,17 , dan 18 & 3 \\
& & Kesiapan membuat keputusan karir & 19,20 , dan 21 & 3 \\
3. & Motivasi (Robbins \& Judge, & Kebutuhan berprestasi & $22,23,24$, dan 25 & 4 \\
& 2009) dan (Riyadi, 2011) & Kebutuhan kekuasaan & 26,27 , dan 28 & 3 \\
& & Kebutuhan berafiliasi & 29,30 , dan 31 & 3 \\
4. & Kinerja karyawan (Robbins \& & Kualitas & 32,33 , dan 34 & 3 \\
& Judge, 2009) dan (Nydia, 2012 & Kuantitas & 25,36, dan 37 & 3 \\
& & Ketepatan waktu & 38 dan 39 & 2 \\
& & Kemandirian & 40 dan 41 & 2 \\
\hline
\end{tabular}

Uji terhadap instrumen berupa uji validitas serta reliabilitas. Uji validitas dikerjakan untuk mendeteksi apakah butirbutir pertanyaan pada kuesioner valid atau tidak. Item-item pertanyaan kuesioner valid apabila pertanyaan kuesioner dapat menjelaskan apa yang akan diukur dengan kuesioner tersebut (Shaputra \& Hendriani, 2015). Valid tidaknya sebuah kuesioner dapat diketahui dengan pengujian menggunakan program SPSS, jika nilai $r$ hitung positif, dan nilai $r$ hitung $>$ nilai $r$ tabel, maka kuesioner itu valid (Widiyanto, 2013). Sedangkan apabila nilai $r$ hitung negatif, dan nilai $r$ hitung $<$ nilai r tabel, maka kuesioner tidak valid.

Uji reliabilitas dibuat untuk mengenali konsistensi jawaban para responden. Instrumen penelitian dinyatakan reliabel seandainya nilai Cronbach's alpha $>0,60$ (Widiyanto, 2013). Ada tiga pendekatan untuk menguji reliabilitas: 1) Koefisien stabilitas, peneliti menguji reliabilitas jawaban responden adalah untuk mengetahui konsistensi jawaban,2)Koefisien ekuivalensi, pengujian menggunakan pengukuran yang berbeda untuk hal yang sama apakah jawaban konsisten, dan 3) Reliabilitas konsistensi internal, konsistensi butir-butir jawaban yang diterima Alat uji yang banyak digunakan adalah Cronbach's alpha.
Analisis penelitian ini menggunakan OLS. Oleh karena itu, penelitian ini diawali dengan uji asumsi klasik. Jenis ujinya adalah uji normalitas, multiklinearitas, dan heteroskedastisitas. Uji normalitas dimaksudkan untuk mencari tahu apakah distribusi datanya normal, atau tidak normal. Kemudian uji normalitas dapat menggunakan hasil pada tabel KolmogorovSmirnov. Seandainya nilai signifikan Asymp. Sig. (2-tailed) lebih besar dari 0,05 maka data penelitian terdistribusi normal (Ghozali, 2013). Pengujian multikolinearitas untuk mencari tahu apakah dalam model regresi linear berganda ditemui adanya hubungan korelasi yang tinggi antara variabel bebas. Salah satu metode untuk menguji multikolinearitas adalah melalui analisis nilai tolerance dan VIF (variance inflation factor). Nilai tolerance rendah artinya sama dengan nilai VIF yang tinggi, ini karena nilai $\mathrm{VIF}=1$ / nilai tolerance. Nilai yang mengindikasikan ada multikolinearitas apabila nilai tolerance $<0,1$ atau sama dengan nilai VIF $(>10)$ (Ghozali, 2013), dan jika nilai VIF $(<10)$, artinya tidak terdapat multikolinearitas. Pengujian heteroskedastisitas adalah untuk mencari tahu apakah terjadi ketidakselarasan varians dari residual satu pengamatan kepada pengamatan lain. Model regresi 
yang baik yaitu, yang model regresinya homoskesdastisitas, yaitu varians dari residual satu pengamatan pengamatan lainnya memiliki sifat yang tetap (Ghozali, 2013). Hasil pengujian heteroskedastisitas dapat juga dicermati dengan memanfaatkan hasil uji Scatterplot.

Pengujian hipotesis pada studi ini menggunakan analisis regresi linear berganda. Dengan analisis ini diharapkan studi ini mengenali pengaruh komitmen organisasional, perencanaan karir, dan motivasi pada kinerja karyawan. Pada model penelitian ini dibuat persamaan sebagai berikut:

$$
\mathbf{Y}=\mathbf{a}+\boldsymbol{\beta} 1 \mathbf{X 1}+\boldsymbol{\beta 2} \mathbf{X} 2+\boldsymbol{\beta 3} \mathrm{X3}+\boldsymbol{\varepsilon}
$$

Catatan: $\mathrm{a}=$ konstanta, $\beta 1=$ koefisien regresi $\mathrm{X} 1, \quad \beta 2=$ koefisien regresi $\mathrm{X} 2$, $\beta 3=$ koefisien regresi $\mathrm{X} 3, \mathrm{X} 1=$ Komitmen Organisasional, $\mathrm{X} 2=$ Perencanaan Karir, X3 = Motivasi, $\mathrm{Y}=$ Kinerja Karyawan, dan $\varepsilon=$ standard error.

Untuk mencari tahu apakah ada atau tidak pengaruh komitmen organisasional, perencanaan karir, dan motivasi pada kinerja karyawan diperlukan pengujian secara parsial. Untuk mencari tahu ada atau tidak pengaruh komitmen organisasional, perencanaan karir, serta motivasi secara bersamaan atau simultan pada kinerja karyawan maka diperlukan pengujian secara simultan. Pengujian ini dikerjakan dengan melihat perbandingan nilai signifikan (Sig.) hasil pada tabel ANOVA dan membandingkan nilai $\mathrm{F}_{\text {hitung }}$ dan $\mathrm{F}_{\text {tabel }}$

Kemudian, analisis koefisien determinasi dikerjakan untuk mendekteksi seberapa mampu model dalam menjelaskan variasi variabel bebas. Nilai $\mathrm{R}^{2}$ adalah antara nol dan satu. Nilai $\mathrm{R}^{2}$ mendekati nol artinya kemampuan variabel bebas (independen) untuk menjelaskan variasi variabel terikat (dependen) terbatas. Sedangkan nilai $\mathrm{R}^{2}$ mendekati satu mengindikasikan variabel bebas (independen) memberikan sebagian besar informasi yang dibutuhkan untuk meramalkan variasi variabel terikat (Ghozali, 2013). Nilai koefisien R Square terlihat pada tabel Model Summary pada hasil pengolahan SPSS.

\section{HASIL DAN PEMBAHASAN}

Kuesioner yang disebar pada media sosial tidak terbatas, dengan kriteria karyawan yang bekerja di organisasi bisnis. Jumlah tanggapan kuesioner yang kembali sebanyak 134 tanggapan, 101 tanggapan untuk karyawan yang bekerja di organisasi bisnis dan 33 tanggapan tidak bekerja pada organisasi bisnis. Hasil tanggapan yang dapat diolah sebanyak 101 tanggapan, karena 33 tanggapan lain tidak memenuhi kriteria responden penelitian.

\section{Analisis Data Deskriptif Responden}

Hasil tanggapan yang didapat dari responden yang bekerja di organisasi bisnis menunjukkan, persentase jenis kelamin responden yang terkumpul dari penyebaran kuesioner adalah $67 \%$ (68 responden) lakilaki dan 33\% (33 responden) perempuan. Usia responden dari data tanggapan yang diperoleh paling banyak 67\% (68 responden) didapatkan pada kisaran usia 18-26 tahun, kemudian 26\% (26 responden) didapatkan pada rentang usia 27-35 tahun sisanya 7\% (7 responden) berada pada kisaran usia 3650 tahun atau lebih. Status kepegawaian responden yang diperoleh berdasarkan tanggapan yang di terima terdapat 54\% (55 responden) dengan status karyawan tetap dan $46 \%$ (46 responden) dengan status karyawan kontrak. Pendidikan terakhir responden terbanyak yaitu tingkat Strata 1 dengan total 65\% (66 responden), kemudian tingkat SMA dengan total $20 \%$ (20 responden), total pada tingkat Diploma 9\% (9 responden), tingkat Strata 2 dengan total 6\% (6 responden). Data masa kerja responden yang diperoleh sebagian besar ada pada masa 1-5 tahun 
masa kerja dengan total 51\% (52 responden), kemudian masa kerja kurang dari satu tahun dengan total $40 \%$ (40 responden), berikutnya masa kerja 6-10 tahun dengan total 7\% (7 responden), masa kerja 11-15 tahun dengan total 1\% (1 responden), dan masa kerja lebih dari 16 tahun dengan total 1\% (1 responden).

\section{Uji Instrumen}

Untuk mengetahui ukuran validitas instrumen penelitian yang digunakan maka dilakukan pengujian validitas. Kuesioner penelitian disebut valid apabila butir pertanyaan yang dilampirkan pada kuesioner menunjukkan $r$ hitung yang lebih besar dari $r$ tabel (Widiyanto, 2013). Untuk pengujiannya menggunakan SPSS. Total tanggapan responden yang memenuhi persyaratan penelitian yang dapat diolah sebanyak $\mathrm{n}=$ 101 tanggapan, tingkat signifikansi yang digunakan yaitu $5 \%$ dari $\mathrm{r}$ tabel didapatkan 0,1956 .
Melihat data hasil di Tabel 2 dapat diketahui jika butir-butir pertanyaan pada variabel komitmen organisasional valid, pernyataan hasil ini diperkuat oleh perbandingan r-tabel yang sebesar 0,1956 $<$ r-hitung semua pertanyaan pada variabel komitmen organisasional, berdasarkan hasil perhitungan SPSS.

Pada data hasil pengujian yang diperoleh di Tabel 3 nampak jelas bahwa semua pertanyaan pada variabel perencanaan karir adalah valid. Pernyataan hasil ini diperkuat oleh perbandingan r-tabel yang sebesar $0,1956<$ r-hitung pada semua pertanyaan pada variabel perencanaan karir, berdasarkan hasil perhitungan SPSS.

Menggunakan data hasil pengujian pada Tabel 4 nampak jelas bahwa semua pertanyaan pada variabel motivasi adalah valid. Pernyataan hasil ini diperkuat oleh perbandingan r-tabel yang sebesar 0,1956 $<$ r-hitung pada semua pertanyaan pada variabel motivasi.

Tabel 2. Uji Validitas untuk Variabel Komitmen Organisasional

\begin{tabular}{|c|c|c|c|c|}
\hline Kode & Pertanyaan Komitmen Organisasional & r tabel & r hitung & Validitas \\
\hline & Komitmen afektif & & & \\
\hline KK1 & Masalah dalam organisasi adalah hal yang penting bagi saya. & 0,1956 & 0,326 & Valid \\
\hline KK2 & Saya senang menceritakan tempat kerja saya dengan orang lain. & 0,1956 & 0,490 & Valid \\
\hline KK3 & Saya merasakan perasaan emosional yang kuat terhadap organisasi. & 0,1956 & 0,466 & Valid \\
\hline KK4 & Saya merasa bangga telah menjadi anggota di dalam organisasi ini. & 0,1956 & 0,513 & Valid \\
\hline \multirow[t]{2}{*}{ KK5 } & Saya senang apabila menghabiskan masa karir di organisasi ini. & 0,1956 & 0,512 & Valid \\
\hline & Komitmen kontinu & & & \\
\hline KK6 & Hidup saya akan terganggu jika meninggalkan perusahaan sekarang. & 0,1956 & 0,650 & Valid \\
\hline KK7 & Bahkan jika saya ingin, meninggalkan perusahaan akan terasa sulit. & 0,1956 & 0,729 & Valid \\
\hline \multirow[t]{2}{*}{ KK8 } & $\begin{array}{l}\text { Sulit untuk menemukan pekerjaan dengan penghasilan yang sebaik } \\
\text { pekerjaan saat ini. }\end{array}$ & 0,1956 & 0,652 & Valid \\
\hline & Komitmen normatif & & & \\
\hline KK9 & Saya merasa berhutang karena perusahaan banyak berjasa bagi saya. & 0,1956 & 0,668 & Valid \\
\hline KK10 & Saya tidak meninggalkan organisasi karena rasa kewajiban moral. & 0,1956 & 0,712 & Valid \\
\hline KK11 & $\begin{array}{l}\text { Saya merasa bersalah meninggalkan organisasi, apalagi kalau hanya } \\
\text { untuk kepentingan pribadi. }\end{array}$ & 0,1956 & 0,633 & Valid \\
\hline
\end{tabular}

Sumber: Pengolahan data primer (2019) 
Pengaruh Komitmen Organisasional, Perencanaan Karir,... (Miswanto, Eggi Sandy Tesa, Bambang S.)

Tabel 3. Uji Validitas untuk Variabel Perencanaan Karir

\begin{tabular}{|c|c|c|c|c|}
\hline Kode & Pertanyaan perencanaan karir & $r$ tabel & r hitung & Validitas \\
\hline & Evaluasi dan penilaian individu & & & \\
\hline PK1 & $\begin{array}{l}\text { Saya mekonfirmasi dan mengevaluasi kemampuan diri agar sesuai } \\
\text { dengan target pekerjaan. }\end{array}$ & 0,1956 & 0,609 & Valid \\
\hline \multirow[t]{2}{*}{ PK2 } & $\begin{array}{l}\text { Saya melakukan penilaian pada diri saya untuk meningkatkan } \\
\text { kemampuan. }\end{array}$ & 0,1956 & 0,762 & Valid \\
\hline & Deskripsi kesempatan peluang karir & & & \\
\hline PK3 & $\begin{array}{l}\text { Saya mencari tahu kesempatan peluang berkarir di dalam maupun di } \\
\text { luar organisasi. }\end{array}$ & 0,1956 & 0,545 & Valid \\
\hline \multirow[t]{2}{*}{ PK4 } & Saya senang dengan kemajuan peluang karir yang tersedia. & 0,1956 & 0,632 & Valid \\
\hline & Penentuan target dan perencanaan karir & & & \\
\hline PK5 & $\begin{array}{l}\text { Saya telah atau akan menentukan target pekerjaan yang ingin saya } \\
\text { capai. }\end{array}$ & 0,1956 & 0,723 & Valid \\
\hline PK6 & $\begin{array}{l}\text { Saya merencanakan kegiatan untuk mendukung pencapaian karir di } \\
\text { masa depan. }\end{array}$ & 0,1956 & 0,735 & Valid \\
\hline \multirow[t]{2}{*}{ PK7 } & Saya telah mencapai tujuan karir jangka pendek. & 0,1956 & 0,552 & Valid \\
\hline & Kesiapan membuat keputusan karir & & & \\
\hline PK8 & $\begin{array}{l}\text { Saya memiliki motivasi atau dorongan yang kuat untuk mencapai karir } \\
\text { yang saya inginkan. }\end{array}$ & 0,1956 & 0,750 & Valid \\
\hline PK9 & $\begin{array}{l}\text { Saya mampu mempelajari keterampilan untuk membuat keputusan } \\
\text { karir. }\end{array}$ & 0,1956 & 0,721 & Valid \\
\hline PK0 & Saya meluangkan waktu dan tenaga untuk membuat keputusan karir & 0,1956 & 0,671 & Valid \\
\hline
\end{tabular}

Sumber: Pengolahan data primer (2019)

Tabel 4. Uji Validitas untuk Variabel Motivasi

\begin{tabular}{|c|c|c|c|c|}
\hline Kode & Pertanyaan motivasi & r tabel & r hitung & Validitas \\
\hline & Kebutuhan untuk berprestasi & & & \\
\hline MT1 & Saya mengusahakan pencapaian standar untuk pekerjaan yang dilakukan. & 0,1956 & 0,476 & Valid \\
\hline MT2 & Saya bersedia melakukan pekerjaan dengan risiko yang relatif tinggi. & 0,1956 & 0,536 & Valid \\
\hline MT3 & Saya mempunyai dorongan untuk maju dalam pekerjaan. & 0,1956 & 0,505 & Valid \\
\hline \multirow[t]{2}{*}{ MT4 } & Saya membutuhkan umpan balik atas pekerjaan yang saya lakukan. & 0,1956 & 0,563 & Valid \\
\hline & Kebutuhan untuk Kekuasaan & & & \\
\hline MT5 & Saya mengusahakan orang lain berperilaku seperti yang saya inginkan. & 0,1956 & 0,526 & Valid \\
\hline MT6 & Saya mengusahakan posisi pemimpin dalam banyak kegiatan. & 0,1956 & 0,705 & Valid \\
\hline \multirow[t]{2}{*}{ MT7 } & Saya berusaha untuk mengendalikan orang lain dalam pekerjaan. & 0,1956 & 0,684 & Valid \\
\hline & Kebutuhan untuk berafiliasi & & & \\
\hline MT8 & Saya bersikap akrab dengan rekan, atasan maupun bawahan. & 0,1956 & 0,557 & Valid \\
\hline MT9 & $\begin{array}{l}\text { Saya menjaga hubungan erat dan sikap korporatif dengan rekan, atasan } \\
\text { dan, bawahan. }\end{array}$ & 0,1956 & 0,562 & Valid \\
\hline MT0 & Saya bersikap ramah dengan rekan, atasan, dan bawahan. & 0,1956 & 0,512 & Valid \\
\hline
\end{tabular}

Sumber: Pengolahan data primer (2019) 
Pada Tabel 5 nampak jelas bahwa semua item-item pertanyaan pada variabel kinerja karyawan adalah valid. Pernyataan hasil ini diperkuat oleh perbandingan nilai r-tabel $=0,1956<$ nilai $r$-hitung semua pertanyaan pada variabel kinerja karyawan, berdasarkan hasil perhitungan SPSS.

Untuk pengukuran variabel atau konstruk penelitian dilakukan dengan uji reliabilitas. Penggunaan reliabilitas dilakukan dengan menggunakan koefisien. Instrumen penelitian yang direkomendasikan Cronbach (1951) adalah minimal bernilai Cronbach's alpha-nya sebesar 0,70 atau lebih tinggi dari 0,60 sebagai batas terendah.
Hasil yang diperoleh menunjukkan jika nilai Cronbach's alpha untuk butirbutir jawaban pada variabel komitmen organisasional, perencanaan karir, dan motivasi lebih besar dari 0,6. Dengan demikian, semua instrumen penelitian adalah reliabel.

\section{Uji Asumsi Klasik}

Nilai signifikan Asymp. Sig. (2-tailed) diperoleh 0,726, lebih besar dari nilai $\alpha=0,05$. Sedangkan hasil uji P-Plot menunjukkan distribusi penyebaran data terarah dan berada di sekitar garis diagonal. Hasil pengujian ini berarti penyebaran data dapat diidentifikasi memiliki distribusi

Tabel 5. Uji Validitas untuk Variabel Kinerja Karyawan

\begin{tabular}{|c|c|c|c|c|}
\hline Kode & Pertanyaan kinerja karyawan & $r$ tabel & r hitung & Validitas \\
\hline & Kualitas & & & \\
\hline EP1 & $\begin{array}{l}\text { Saya mampu menyelesaikan pekerjaan dengan tepat dan teliti seperti yang } \\
\text { diinginkan. }\end{array}$ & 0,1956 & 0,748 & Valid \\
\hline EP2 & $\begin{array}{l}\text { Hasil pekerjaan saya telah sesuai dengan standar yang sudah ada di } \\
\text { perusahaan. }\end{array}$ & 0,1956 & 0,742 & Valid \\
\hline \multirow[t]{2}{*}{ EP3 } & Pekerjaan yang saya kerjakan telah sesuai dengan prosedur yang ditetapkan. & 0,1956 & 0,547 & Valid \\
\hline & Kuantitas & & & \\
\hline EP4 & Saya dapat menyelesaikan beberapa target pekerjaan. & 0,1956 & 0,638 & Valid \\
\hline EP5 & Saya dapat bekerja dengan baik, bahkan jika sedang banyak pekerjaan. & 0,1956 & 0,606 & Valid \\
\hline \multirow[t]{2}{*}{ EP6 } & Saya dapat menyelesaikan pekerjaan melebihi target harian yang ditetapkan. & 0,1956 & 0,680 & Valid \\
\hline & Ketetapan waktu & & & \\
\hline EP7 & Waktu yang diberikan cukup bagi saya untuk menyelesaikan pekerjaan. & 0,1956 & 0,673 & Valid \\
\hline \multirow[t]{2}{*}{ EP8 } & $\begin{array}{l}\text { Saya akan memanfaatkan waktu kerja yang tersisa untuk melakukan } \\
\text { pekerjaan lain. }\end{array}$ & 0,1956 & 0,686 & Valid \\
\hline & Kemandirian & & & \\
\hline EP9 & Saya mampu menyelesaikan pekerjaan saya dengan mandiri. & 0,1956 & 0,660 & Valid \\
\hline EP0 & Saya bisa mendapat solusi masalah pekerjaan dari pengetahuan saya. & 0,1956 & 0,761 & Valid \\
\hline
\end{tabular}

Sumber: Pengolahan data primer (2019)

Tabel 6. Hasil Uji Reliabilitas

\begin{tabular}{llrc}
\hline & Variabel & Cronbach's alpha & Keterangan \\
\hline X1 & Komitmen Organisasional & 0,807 & Reliabel \\
X2 & Perencanaan Karir & 0,857 & Reliabel \\
X3 & Motivasi & 0,752 & Reliabel \\
Y & Kinerja Karyawan & 0,861 & Reliabel \\
\hline
\end{tabular}

Sumber: Pengolahan data primer (2019) 
normal. Uji multikolinearitas dilakukan dengan dengan membandingkan nilai VIF, yang menunjukkan variabel komitmen organisasional, perencanaan karir, dan motivasi mempunyai nilai VIF lebih kecil dari 10 dan nilai tolerance lebih besar dari 0,1 . Oleh karena itu, data penelitian ini berindikasi tidak ada multikolinearitas. Uji heteroskedastisitas menggunakan uji Glejser. Nilai Sig. $(X 1=0,058 ; X 2=0,651 ; X 3=0,295)$ dibandingkan dengan $\alpha=5 \%$. Hasilnya nilai signikansi variabel independen lebih besar dari nilai $\alpha=5 \%$. Sehingga dikatakan bahwa model regresi estimasi tidak ada masalah heteroskedastisitas.

\section{Analisis Regresi Linear Berganda}

Analisis ini dimaksudkan untuk mencari tahu apakah variabel komitmen organisasional, perencanaan karir, dan motivasi mampu mempengaruhi kinerja karyawan. Koefisien regresi, t hitung dan nilai probabilitas tersaji pada Tabel 7 .

Tabel 7. Hasil Analisis Regresi Linear Berganda

\begin{tabular}{llccc}
\hline & Variabel & $\begin{array}{c}\text { Koefisien } \\
\text { Regresi }\end{array}$ & t hitung & Sig. \\
\hline X & Konstanta & 7,067 & & 0,069 \\
Komitmen & 0,038 & 0,587 & 0,558 \\
Xrganisasional & & & \\
X2 & $\begin{array}{l}\text { Perencanaan } \\
\text { Karir }\end{array}$ & 0,402 & 3,742 & 0,000 \\
X3 & Motivasi & 0,378 & 3,152 & 0,002 \\
& F hitung $=26,215$ & & \\
& Adjusted R2 $=0,431$ & & \\
\hline
\end{tabular}

Sumber: Pengolahan data primer (2019)

Menggunakan data yang diperoleh pada hasil uji regresi berganda Tabel 7 dengan SPSS, berikut adalah persamaan regresi.

$$
\begin{aligned}
& \mathrm{Y}=\mathbf{7 , 0 6 7}+\mathbf{0 , 0 3 8} \mathrm{X} 1+\mathbf{0 , 4 0 2} \mathrm{X} 2+\mathbf{0 , 3 7 8} \\
& \mathrm{X} 3+\varepsilon
\end{aligned}
$$

Diasumsikan faktor lain tidak berubah, koefisien-koefisien pada persamaan regresi tersebut dideskripsikan sebagai berikut.
Pertama, besarnya nilai konstanta sama dengan 7,067 artinya, apabila variabel komitmen organisasional, perencanaan karir, dan motivasi sama dengan nol, artinya kinerja karyawan sama dengan atau sebesar 7,067. Kedua, besarnya nilai koefisien beta variabel komitmen organisasional (X1) positif sebesar 0,038 , artinya jika terjadi peningkatan sebesar satu satuan variabel komitmen organisasional (X1) maka akan berakibat pada peningkatan kinerja karyawan sebesar 0,038 satuan. Ketiga, besarnya nilai koefisien beta variabel perencanaan karir (X2) positif sebesar 0,402, artinya jika terjadi peningkatan sebesar satu satuan variabel perencanaan karir (X2) maka berakibat pada peningkatan kinerja karyawan sebesar 0,402 satuan. Jika yang terjadi sebaliknya akan berakibat pada penurunan kinerja karyawan sebesar 0,402 satuan. Keempat, besarnya nilai koefisien beta untuk variabel motivasi (X3) positif sebesar 0,378, artinya jika ada kenaikan sebesar satu satuan variabel motivasi (X3) maka akan berakibat ada peningkatan kinerja karyawan sebesar 0,378 satuan. Apabila terjadi sebaliknya akan berakibat pada penurunan kinerja karyawan sebesar 0,378 satuan.

\section{Uji Hipotesis}

Analisis uji parsial dilakukan pada penelitian ini untuk mencari tahu apakah variabel komitmen organisasional, perencanaan karir, dan motivasi secara parsial mampu mempengaruhi kinerja karyawan. Pada uji parsial (uji t) penelitian ini, nilai t tabelnya adalah 1,9847 . Informasi nilai $t$ hitung dapat diketahui dengan melihat Tabel 7 sedangkan informasi df dapat dilihat pada tabel ANOVA. Variabel komitmen organisasional (X1) memiliki nilai t hitung 0,587 lebih kecil dari nilai t tabel 1,9847 atau memiliki nilai probabilitas 0,558 lebih besar dari 5\%. Artinya variabel komitmen organisasional secara parsial tidak mampu mempengaruhi dengan signifikan variabel kinerja karyawan. Variabel perencanaan karir 
(X2) dengan nilai thitung adalah 3,742, lebih tinggi dari nilai t tabel 1,9847, atau memiliki nilai probabilitas 0,00 lebih kecil dari $5 \%$. Maksudnya variabel perencanaan karir signifikan berpengaruh positif pada variabel kinerja karyawan. Variabel motivasi (X3) dengan $t$ hitung sebesar 3,152 adalah lebih besar dari t tabel yang sebesar 1,9847, atau memiliki nilai probabilitas 0,002 lebih kecil dari $5 \%$. Artinya variabel motivasi signifikan berpengaruh positif terhadap variabel kinerja karyawan. Berdasar hasil pengujian tersebut, ringkasan hasil pada pengujian hipotesis tersaji pada Tabel 8.

Tabel 8. Hasil Pengujian Hipotesis

\begin{tabular}{clc}
\hline & \multicolumn{1}{c}{ Hipotesis } & Keterangan \\
\hline $\mathrm{H}_{1}$ & $\begin{array}{l}\text { Komitmen Organisasional } \\
\text { Berpengaruh Positif pada Kinerja }\end{array}$ & Ditolak \\
& $\begin{array}{l}\text { Karyawan } \\
\mathrm{H}_{2}\end{array}$ & $\begin{array}{l}\text { Perencanaan Karir Berpengaruh } \\
\text { Positif pada Kinerja Karyawan }\end{array}$ \\
$\mathrm{H}_{3}$ & $\begin{array}{l}\text { Perencanaan Karir Berpengaruh } \\
\text { Positif pada Kinerja Karyawan }\end{array}$ & Diterima \\
\hline
\end{tabular}

Sumber: Pengolahan data primer (2019)

\section{Analisis Simultan dan Koefisien Determinasi}

Analisis uji simultan pada penelitian ini dilakukan untuk mencari tahu apakah variabel komitmen organisasional, perencanaan karir, dan motivasi berpengaruh pada kinerja karyawan secara simultan. Menggunakan data hasil uji regresi berganda dengan SPSS, berikut ini hasil pengujian secara simultan.

Tabel 9. Hasil Uji Simultan

\begin{tabular}{lccc}
\hline & $\begin{array}{c}\text { F } \\
\text { hitung }\end{array}$ & $\begin{array}{c}\text { F } \\
\text { tabel }\end{array}$ & $\begin{array}{c}\text { Nilai } \\
\text { Signifikansi }\end{array}$ \\
\hline $\begin{array}{l}\text { Komitmen organisasional, } \\
\text { perencanaan karir, dan }\end{array}$ & 26,22 & 2,70 & 2,70 \\
motivasi secara simultan & & & \\
berpengaruh pada kinerja & & \\
karyawan \\
$\begin{array}{l}\alpha=5 \%(0,05) \\
(\text { df.: v1 }=3 ; \text { v2 }=97)\end{array}$
\end{tabular}

Sumber: Pengolahan data primer (2019)
Untuk pengujian secara simultan (uji F) nilai $\mathrm{F}$ tabel yang diperoleh adalah 2,70. Informasi $\mathrm{F}$ hitung dapat dilihat dari ANOVA tabel adalah 26,22. Pengujian dilakukan dengan melihat perbandingan antara nilai $\mathrm{F}$ hitung dan $\mathrm{F}$ tabel atau pembandingan antara nilai signifikansi dan 5\%. Diketahui jika nilai $\mathrm{F}$ hitung adalah 26,22 lebih tinggi dari $\mathrm{F}$ tabel yang sebesar 2,70, atau tingkat signifikansi 0,00 lebih kecil dari 5\%. Artinya variabel komitmen organisasional, perencanaan karir, dan motivasi berpengaruh secara simultan pada kinerja karyawan.

Analisis koefisien determinasi yang dilakukan pada studi ini bermaksud untuk mencari tahu seberapa besar kemampuan variabel komitmen organisasional, perencanaan karir, dan motivasi dapat menjelaskan variasi kinerja karyawan. Hasil koefisien determinasi dapat dihitung dengan nilai Adjusted $\mathrm{R}^{2}$. Nilai Adjusted $\mathrm{R}^{2}$ diketahui sebesar 0,431 sehingga variabel komitmen organisasional, perencanaan karir, dan motivasi mampu menjelaskan $43,1 \%$ variasi kinerja karyawan. Sedangkan, sisanya 56,9\% variasi variabel kinerja karyawan dijelaskan oleh variabel independen di luar penelitian.

\section{Pembahasan}

Pembahasan pertama adalah pengaruh komitmen organisasional pada kinerja karyawan. Hasil pengujiannya mengindikasikan bahwa variabel komitmen organisasional tidak signfikan berpengaruh positif pada kinerja karyawan. Penelitian Sturgis (2002) di Inggris menemukan jika komitmen berdampak negatif langsung pada perilaku karir karyawan yang ingin mengembangkan karir di luar organisasi. Cho \& Barak (2008) menemukan jika karyawan yang berkomitmen yaitu pria, karyawan yang lebih tua dan karyawan dengan posisi jabatan yang tinggi. Hal ini tidak sesuai dengan sebagian besar responden berada pada rentang usia 18-35 tahun yang termasuk dalam rentang usia generasi milenial. 
Deloitte.com (2019) menyatakan bahwa riset yang dilakukan IBM (2014) di 12 negara pada 6 industri dengan 1700 karyawan menemukan jika $42 \%$ generasi milenial mudah beralih pekerjaan. Deloitte. com (2019) juga menyatakan bahwa survei yang dilakukan oleh perusahaan rekrutmen global Hays (2018) menemukan jika ada sekitar 38\% karyawan Asia yang aktif melihat peluang kerja baru. Sekitar $42 \%$ karyawan merasa terbuka dengan adanya peluang kerja baru, sedangkan yang terjadi di Amerika Serikat hampir $60 \%$ karyawan aktif mencari peluang baru.

Pembahasan kedua adalah pengaruh perencanaan karir pada kinerja karyawan. Hasil pengujiannya mengindikasikan bahwa perencanaan karir signifikan berpengaruh positif pada kinerja karyawan. Oleh karena itu, bagi karyawan perencanaan karir menjadi sebuah pertimbangan penting, karena mampu mendorong usaha pencapaian tujuan karir yang berdampak pada baiknya kinerja mereka di perusahaan. Selain itu, kegiatan evaluasi, penentuan target karir, dan pencarian peluang karir yang dilakukan secara mandiri oleh karyawan mendorong peningkatan kinerja mereka. Hasilnya studi ini sesuai dengan hasil studi Massie, et all. (2015) yaitu perencanaan karir memiliki pengaruh positif pada kinerja karyawan.

Pembahasan ketiga adalah pengaruh motivasi pada kinerja karyawan.Hasil pengujiannya mengindikasikan bahwa motivasi signifikan berpengaruh positif pada kinerja karyawan. Oleh karena itu diindikasikan bahwa motivasi berpengaruh positif pada kinerja karyawan. Pengaruh ini menunjukkan jika kebutuhan karyawan untuk berprestasi, untuk memiliki kekuasaan pada lingkungan kelompok kerja dan memiliki hubungan antar personal yang baik dengan orang-orang di sekitar lingkungan kerja mampu meningkatkan kinerja karyawan. Hasil penelitian ini sesuai dengan temuan Paputungan (2013) dan Harlie (2011) bahwa motivasi dapat memiliki pengaruh positif pada kinerja karyawan.

\section{SIMPULAN DAN SARAN}

Simpulan penelitian diuraikan seperti berikut. Pertama, komitmen organisasional tidak berpengaruh positif pada karyawan. Kedua, perencanaan karir signifikan memiliki pengaruh positif pada kinerja karyawan. Ketiga, motivasi signifikan berpengaruh positif pada kinerja karyawan. Keempat, secara simultan, ketiga variabel independen mampu mempengaruhi variabel kinerja karyawan. Kelima, ketiga variabel independen mampu memberikan kontribusi pengaruhnya terhadap kinerja karyawan sebanyak $44,8 \%$.

Keterbatasan penelitian ini adalah hanya meneliti tiga variabel independen yang mempengaruhi kinerja karyawan. Ketiga variabel tersebut adalah komitmen organisasional, perencanaan karir, dan motivasi karyawan. Dalam teori-teori pada manajemen sumberdaya manusia, masih banyak variabel yang mempengaruhi kinerja karyawan. Beberapa saran untuk perbaikan penelitian sebagai berikut: pertama, pendekatan yang berbeda seperti wawancara dapat dilakukan pada penelitian selanjutnya, dengan mengawasi perolehan tanggapan dari responden secara langsung. Hal ini karena penyebaran dengan media online tidak dapat diawasi, sehingga berpotensi terjadi kesalahan pada saat pengisian. Kedua, variabel independen yang dipilih pada penelitian ini adalah faktor-faktor internal karyawan. Penelitian selanjutnya dapat menambahkan atau menggunakan faktor eksternal karyawan sebagai variabel independen.Ketiga, respondenpadapenelitian ini terbatas dan berasal dari organisasi bisnis yang berbeda-beda. Pada penelitian berikutnya dapat mengamati sampel yang diambil dari berbagai organisasi bisnis yang dikelompokkan berdasar industri. Dengan 
ada pengelompokkan organisasi bisnis berdasar industrinya, penelitian berikutnya mungkin akan memberikan gambaran yang berbeda mengenai faktor-faktor yang benarbenar memiliki pengaruh terhadap kinerja karyawan pada setiap industri.

\section{REFERENSI}

Algifari. (2013). Statistika Induktif Untuk Ekonomi dan Bisnis. Yogyakarta: STIE YKPN Yogyakarta.

Allen, N. J., \& Meyer, J. P. (1993). Organizational Commitment: Evidence of career stage effects? Journal of Business Research, 26(1), 49-61.

Baldoni, John . (2005). Great Motivation Secret of Great Leaders. New York: McGraw-Hill.

Brown, S. P., \& Leigh, T. W. (1996). A New Look at Psychological Climate and its Relationship to Job Involvement Effort and Performance. Journal of Applied Psychology, 81(4), 358-368.

Byars, L. \& Rue, L. (2008). Human Resource Management. New York: McGrawHill/Irwin.

Cho, S. \& Barak. (2008). Understanding of Diversity and Inclusion in a Perceived Homogeneous Culture: A Study of Organizational Commitment and Job Performance among Korean Employees. Administration in Social Work, 32(4), 100-126.

Fitriastuti, T. (2013). Pengaruh Kecerdasan Emosional, Komitmen Organisasi, dan Organizational Citizenship Behavior terhadap Kinerja Karyawan. Jurnal Dinamika Manajemen, 4(2), 103-114.

Ghozali, Imam. (2013). Aplikasi Analisis Multivariat dengan Program IBM
SPSS 21. Semarang: Badan Penerbit Universitas Diponegoro.

Harlie, M. (2012). Pengaruh Disiplin Kerja, Motivasi dan Pengembangan Karir terhadap Kinerja Pegawai Negeri Sipil pada Pemerintah Kabupaten Tabalong di Tanjung Kalimantan Selatan. Jurnal Aplikasi Manajemen, 10(4), 860-867.

Indriantoro, N. \& Supomo, B. (2016). Metodologi Penelitian Bisnis Untuk Akuntasi dan Manajemen. Yogyakarta: BPFE Yogyakarta.

Kaya, S, Didem., \& Zerenler, Muammer. (2014). A Model Proposed to Determine the Effects of Career Planning on the Relation Between Psychological Capital and Occupational Commitment. The Journal of International Social Research, 7(34), 865-874.

Kirk, L \& O'Connell., T (2012). Challenges Facing Field Instructors Employed in Wilderness-Based Expeditionary Programs A Review of Literature. A Student Hournal in Recreation, Parks and Leisure Studies, 10(1), 17-27.

London, M., \& Noe, R. (1997). London's Career Motivation Theory: An Update on Measurement and Research. Journal of Career Assesment, 5(1), 61-80.

Massie, R., Tewal, B., \& Sendow, G. (2015). Pengaruh Perencanaan Karir, Pelatihan dan Pengembangan Karir Terhadap Kinerja Pegawai pada Museum Negeri Provinsi Sulawesi Utara. Jurnal Berkala Ilmiah Efisiensi, 15(5), 635-645.

McAuliffe. G., Jurgens. J. C., Pickering. Worth., Calliotte. James., Macera. Anthony., \& Zerwas. Steven. (2006). Targeting low career confidence using the career planning confidence 
scale. Journal of employment counseling, 43(3), 117-129.

Mulyadi, R., Hidayati, T. \& Maria, S. (2018). Pengaruh Petencanaan Karir, Pelatihan, dan Pengembangan Karir Terhadap Kinerja Karyawan. Journal FIB UNMUL, 15(1), 29-37.

Murty, W. A., \& Hudiwinarsih, G. (2012). Pengaruh Kompensasi, Motivasi dan Komitmen Organisaional Terhadap Kinerja Karyawan Bagian Akuntansi (Studi Kasus pada Perusahaan Manufaktur di Surabaya). The Indonesian Accounting Review, 2(2), 215-228.

Nydia, Yetta Tri. (2012). Pengaruh Komitmen Organisasional Terhadap Kinerja Karyawan Lapangan SPBU COCO Pertamina Mt Haryono. Skripsi, Fisip UI.

Paputungan, F. R. (2013). Motivasi, Jenjang Karir, dan Disiplin Kerja Pengaruhnya Terhadap Kinerja Karyawan Pada PT. BANK Sulut Cabang Calaca. Jurnal EMBA, 1(4), 679-688.

Rimper, R. R., \& Kawet, L. (2014). Pengaruh Perencanaan Karir dan Self Efficacy Terhadap Kinerja Karyawan pada PT. PLN (Persero) area Manado. Jurnal EMBA, 2(4), 413-423.

Riyadi,Slamet.(2011).Pengaruh Kompensasi Finansial, Gaya Kepemimpinan, dan Motivasi Kerja Terhadap Kinerja Karyawan pada Perusahaan Manufaktur di Jawa Timur. Jurnal Manajemen dan Kewirausahaan, 13(1), 40-45.

Robbins. S. P., d. J. (2009). Organizational Behavior. New Jersey: Pearson Prentice Hall.

Setiawan, S. R. D. (2018, Februari 14). Terungkap,3 AlasanUtamaKaryawan "Resign". Diambil kembali dari
Kompas: https://ekonomi.kompas. $\mathrm{com} / \mathrm{read} / 2018 / 02 / 14 / 072800926 /$ terungkap- 3 - a las a n-u tamakaryawan-resign-

Shaputra, A. R., \& Hendriani, S. (2015). Pengaruh Kompentensi, Komitmen dan Pengambangan Karir Terhadap Kinerja Karyawan PT. Bank Rakyat Indonesia (Persero) Kantor Wilayah Pekanbaru. Jurnal Tepak Manajemen Bisnis, 7(1), 1-20.

Spik, Aleksandra. (2016). Enthusiasts or Trapped? Relations Between Organizational Commitment Profiles, Organizational Citizenship Behavior and Life Satisfaction. Journal of Entrepreneurship, Management and Innovation (JEMI), 12(1), 7-34.

Turges, J., Guest, D., Conway, N., \& Davey, K. M. (2002). A Longitudinal Study of the Relationship between Career Management and Organizational Commitment among Graduates in the First Ten Years at Work. Journal of Organizational Behavior, .23(6), 731-748.

Sugiharjo, R. J., \& Rustinah. (2017). Pengaruh Perencanaan Karir, Pengembangan Karir Karyawan, dan Kompensasi Terhadap Karyawan pada Jambuluwuk Puncak Resort. Jurnal Ilmiah Manajemen dan Bisnis, 3(3), 444-454.

Ticoalu, L. K. (2013). Organizational Citizenship Behavior (OCB) dan Komitmen Organisasi Pengaruhnya Terhadap Kinerja Karyawan. Jurnal EMBA, 1(4), 782-790.

Widiyanto, M. A. (2013). Statistika Terapan: Konsep dan Aplikasi SPSS/LISREL dalam Penelitian Pendidikan, Psikologi dan Ilmu Sosial. Jakarta; Elek Media Komputindo.

Wijaya, N.H.S. dan Prabandari, P. (2019). Hubungan Antara Kualitas 
Kehidupan Kerja, Sinergi KantorRumah, Kepuasan Kerja, dan Kinerja Pegawai: Survey di Kec. Depok, Sleman, DIY. Jurnal Manajemen, 16(2), 141-154.

www2.deloitte.com. (2019). Generasi Milenial dalam Industri 4.0: Berkah Bagi Sumber Daya Manusia Indonesia atau Ancaman?. Deloitte Indonesia Perspectives. Edisi Pertama.

Zurnali. Cut. (2010). Learning Organization, Competency, Organizational Commitment, dan Customer Orientation: Kowledge WorkerKerangka Riset Mnajemen Sumber Daya Manusia pada Masa Depan. Bandung: Unpad Press. 